\title{
Pengambilan Minuta Akta Dan Pemanggilan Notaris Serta Hak Ingkar Notaris Berdasarkan Sumpah Jabatan Notaris Dalam Pemeriksaan Perkara Perdata Di Pengadilan
}

\author{
Kristi W. Simanjuntak \\ Fakultas Hukum, Universitas Muhammadiyah Sorong \\ Email : Kristiwarista98@gmail.com
}

\begin{abstract}
Abstrak
Penelitian ini bertujuan untuk menganalisis bagaimana persetujuan Majelis Kehormatan Notaris (MKN) terkait pengambilan minuta akta dan pemanggilan Notaris dalam pemeriksaan perkara perdata, dan bagaimana tanggung jawab Notaris saat memberikan keterangan di pengadilan dalam pemeriksaan perkara perdata, terkait hak ingkar dan rahasia jabatan Notaris. Metode penelitian yang digunakan dalam penelitian ini metode yuridis normatif, artinya suatu penelitian yang bertumpu pada peraturan perundang-undangan (statute approach) dan pendekatan konsep (conseptual approach) dengan ditopang studi kepustakaan relevan dengan permasalahan dibahas kemudian dianalisis dan disimpulkan dalam penulisan. Hasil penelitian ini menunjukan bahwa berdasarkan ketentuan peraturan perundang-undangan yang mengatur tentang mekanisme pengambilan Minuta Akta dan Pemanggilan Notaris dengan persetujuan Majelis Kehormatan Notaris dalam pemeriksaan perkara perdata di Pengadilan, dapat disimpulkan bahwa untuk kepentingan proses peradilan, para pihak ataupun hakim, terlebih dahulu harus mendapatkan persetujuan Majelis Kehormatan Notaris. Di samping itu, berdasarkan peraturan perundangundangan yang mengatur tentang pengambilan Minuta Akta dan Pemanggilan Notaris, pengaturan tentang kedudukan Notaris sebagai tergugat atau turut tergugat dalam perkara perdata tidak disebutkan secara tegas. Beberapa hal penting yang mengatur pengambilan Minuta Akta dan Pemanggilan Notaris sebagian besar hanya mengatur tentang kedudukan Notaris sebagai saksi atau tersangka dalam perkara pidana. Berkaitan dengan tanggung Jawab notaris dalam pemeriksaan perkara perdata di pengadilan terkait rahasia jabatan dan hak ingkar notaris dalam meemberikan keterangan di pengadilan oleh Notaris terkait akta yang dibuatnya bersifat fakultatif, walaupun pada akhirnya keputusan akhir dari pemberian izin tersebut didasarkan kepada pertimbangan Majelis Kehormatan Notaris, ataupun juga berdasarkan keputusan hakim yang mewajibkan Notaris memberikan keterangan di pengadilan sehingga hak ingkar Notaris yang berkaitan dengan sumpah jabatan Notaris menjadi berakhir. Dalam kondisi yang demikian, Notaris harus mendapatkan perlindungan hukum atas keterangan yang diberikannya, termasuk bebas dari sanksi hukum yang mengatur tentang rahasia jabatan
\end{abstract}

Kata Kunci : Pengambilan Minuta Akta, Hak Ingkar Notaris , Sumpah Jabatan Notaris

\section{PENDAHULUAN}

Sebagai pejabat umum yang diangkat oleh Negara, Notaris memiliki kewajiban dan kewenang yang diatur secara khusus dalam Undang-Undang Nomor 30 Tahun 2004 tentang Jabatan Notaris, sebagaimana telah diubah dengan UU Nomor 2 tahun 2014 tentang perubahan atas undang-undang nomor 30 tahun 2004 tentang Jabatan Notaris (selanjutnya disebut UUJN). 
Pasal 1 angka (1) UUJN menyatakan bahwa yang disebut sebagai Notaris adalah pejabat umum yang berwenang untuk membuat akta autentik dan memiliki kewenangan lainnya sebagaimana dimaksud dalam Undang-Undang ini atau berdasarkan undang-undang lainnya.

Notaris berperan dalam membantu menciptakan kepastian dan perlindungan hukum bagi masyarakat bersifat preventif terhadap masalah hukum dengan cara penerbitan akta otentik terkait status hukum, hak dan kewajiban seseorang dalam hukum dan lain sebagainya, yang berfungsi sebagai alat bukti di Pengadilan jika terjadi sengketa. Hal ini berkaitan dengan produk hukum yang dihasilkan oleh Notaris yakni berupa Akta Otentik, yakni sebagai alat bukti terkuat dan terpenuh sehingga mempunyai peranan penting dalam setiap hubungan hukum dalam kehidupan masyarakat. Akta otentik menentukan secara jelas hak dan kewajiban, menjamin kepastian hukum, dan sekaligus diharapkan dapat pula dihindari terjadinya sengketa.

Notaris dalam menjalankan tugas jabatannya, tidak jarang ditemui permasalahanpermasalahan, baik terhadap akta yang dibuatnya maupun terhadap para pihak yang terlibat dalam pembuatan akta tersebut. Notaris seringkali diikut-sertakan dalam sengketa yang terjadi antara pihak oleh karena akta yang dibuatnya menimbulkan kerugian bagi salah satu pihak. Jika kerugian tersebut diduga berasal dari pelanggaran atau kelalaian yang dilakukan Notaris, maka pihak yang merasa dirugikan kadang-kadang menuntut Notaris yang bersangkutan dengan cara mengajukan gugatan ke Pengadilan. Keberadaan UUJN dimaksudkan tidak hanya untuk menggali kebenaran materiil dari suatu akta, tetapi juga dimaksudkan untuk mendapatkan kejelasan alat bukti yang berupa akta otentik (Djoko Sukisno, 2008:53).

Berkaitan dengan keterlibatan Notaris dalam proses peradilan, dalam hubungannya dengan pengambilan minuta akta dan pemanggilan Notaris, untuk kepentingan proses peradilan, penyidik, penuntut umum, atau hakim, sebelumnya dalam UUJN 30/04 kewenangan tersebut diberikan kepada Majelis Pengawas Daerah. Setelah perubahan, dalam UUJN 2/14 kewenangan tersebut ada pada Majelis Kehormatan Notaris, sebagaimana termaktub dalam Pasal 66 UUJN. Pasal 66 UUJN menentukan sebagai berikut. Prosedur khusus dalam penegakkan hukum terhadap Notaris yang diatur dalam Pasal 66 UUJN yaitu ; (1) Untuk kepentingan proses peradilan, penyidik, penuntut umum, atau hakim dengan persetujuan majelis kehormatan Notaris berwenang; (a) mengambil fotokopi Minuta Akta dan/atau surat-surat yang dilekatkan pada Minuta Akta atau Protokol Notaris dalam penyimpanan Notaris; dan (b) memanggil Notaris untuk hadir dalam pemeriksaan yang berkaitan dengan Akta atau Protokol Notaris yang berada dalam penyimpanan Notaris; (2) 
Pengambilan fotokopi Minuta Akta atau surat-surat sebagaimana dimaksud pada ayat (1) huruf a, dibuat berita acara penyerahan; (3) Majelis kehormatan Notaris dalam waktu paling lama 30 (tiga puluh) hari kerja terhitung sejak diterimanya surat permintaan persetujuan sebagaimana dimaksud pada ayat (1) wajib memberikan jawaban menerima atau menolak permintaan persetujuan; (4) Dalam hal majelis kehormatan Notaris tidak memberikan jawaban dalam jangka waktu sebagaimana dimaksud pada ayat (3), majelis kehormatan Notaris dianggap menerima permintaan persetujuan.

Pasal 66 UUJN disamping memberi wewenang untuk mengambil fotokopi Minuta Akta dengan persetujuan Majelis Kehormatan Notaris, juga memberi wewenang kepada hakim untuk memanggil Notaris dalam pemeriksaan sehubungan dengan akta yang dibuatnya. Pemanggilan Notaris dalam Pasal tersebut dapat ditafsirkan memanggil Notaris sebagai saksi atau sebagai salah satu subyek yang diperiksa terkait akta yang dibuatnya. Tujuan pengambilan Minuta Akta dan pemanggilan Notaris dimaksudkan untuk menemukan fakta hukum yang mempunyai pengaruh penting dalam proses pemeriksaan perkara di pengadilan, sehingga pemanggilan tersebut diharapkan dapat membantu memperlancar proses peradilan.

Pelaksanaan dari Pasal 66 UUJN kemudian diatur lebih lanjut dalam Peraturan Menteri Hukum dan Hak Asasi Manusia Nomor M.03.HT.03.10 Tahun 2007 tentang Pengambilan Minuta AKta dan Pemanggilan Notaris (selanjutnya disebut Permenkum HAM). Namun Permenkum HAM tersebut hanya mengatur mengenai prosedur pemangggilan Notaris dan pengambilan Minuta Akta dalam kedudukan Notaris sebagai saksi atau tersangka dalam perkara pidana, sedangkan kedudukan Notaris sebagai tergugat atau turut tergugat dalam suatu perkara perdata belum ada pengaturannya.

Selain itu, Permenkumham Nomor M.03.HT.03.10 Tahun 2007 tentang Pengambilan Minuta AKta dan Pemanggilan Notaris, memberikan wewenang kepada Majelis Pengawas Daerah dalam hal pemberian persetujuan terhadap protokol Notaris, dimana kewenangan Majelis Pengawas Daerah sekarang ini diberikan kepada Majelis Kehormatan Notaris berdasarkan Putusan Mahkamah Konstitusi Nomor 49/PUU-X/2012 dan Putusan Mahkamah Konstitusi Nomor 72/PUU-XII/2014. Pengambilan Minuta Akta dan Pemanggilan Notaris juga dalam kewenangan Majelis Kehormatan Notaris diatur dalam Permenkum HAM Nomor 7 tahun 2016 tentang Majelis Kehormatan Notaris (selanjutnya disebut Permenkum HAM 7/16). 
Pemanggilan Notaris sebagai saksi dalam pemeriksaan perkara perdata dapat terjadi, jika akta sebagai alat bukti dirasa tidak cukup, sehingga kehadiran Notaris dipandang perlu untuk memberikan keterangan terkait sengketa yang sedang terjadi. Apalagi jika keterangan yang diberikan Notaris sangat urgen dan relevan meneguhkan dalil penggugat atau bantahan tergugat. Pemanggilan oleh hakim terhadap saksi yang diperlukan didasarkan atas permintaan salah satu pihak berdasarkan Pasal 139 HIR, yakni dalam hal mereka tidak dapat menghadirkan saksi yang penting ke persidangan (Harahap, 2008:213).

Kehadiran notaris dipersidangan untuk memberikan keterangan, baik dalam kedudukannya sebagai saksi ataupun tergugat tentu saja akan berbenturan dengan rahasia jabatan Notaris sebagaimana termuat dalam sumpah jabatan Notaris. Dalam sumpah jabatan Notaris dinyatakan bahwa, Notaris bersumpah akan merahasiakan isi akta dan keterangan yang diperoleh dalam pelaksanaan jabatan dan akan patuh pada UUJN. Disamping itu jabatan Notaris sebagai suatu jabatan kepercayaan berkewajiban merahasiakan semua apa yang diberitahukan kepadanya selaku Notaris, Notaris tidaklah bebas untuk memberitahukan apa yang diberitahukan kepadanya selaku Notaris oleh Kliennya pada waktu diadakan pembicaraan sebagai persiapan untuk pembuatan akta, sekalipun tidak semua yang dibicarakan itu dicantumkan dalam akta.

Kewajiban Notaris untuk mejaga rahasia jabatannya juga diatur dalam Pasal 1909 ayat (2) angka 3e BW dan Pasal 170 KUHAP yakni mengenai pembebasan sebagai saksi karena pekerjaan atau jabatannya diwajibkan menyimpan rahasia atau yang dikena dengan hak ingkar. Hak ingkar merupakan pengecualian terhadap ketentuan umum yang menyatakan bahwa setiap orang yang cakap memberikan saksi berkewajiban memberikan kesaksian dimuka pengadilan, baik dalam proses perdata maupun dalam proses pidana.

Berdasarkan uraian diatas, maka dapat dikemukakan permasalahan sebagai berikut : (1) Bagaimana mekanisme pengambilan Minuta Akta dan pemanggilan Notaris dengan persetujuan Majelis Kehormatan Notaris dalam pemeriksaan perkara perdata di Pengadilan ?Bagaimana tanggung Jawab Notaris Dalam Pemeriksaan Perkara Perdata di Pengadilan Terkait Rahasia Jabatan dan Hak Ingkar Notaris?

PEMBAHASAN

Mekanisme pengambilan Minuta Akta dan pemanggilan Notaris dengan persetujuan Majelis Kehormatan Notaris dalam pemeriksaan perkara perdata di Pengadilan 
Dalam konstruksi hukum kenotariatan, salah satu tugas jabatan Notaris yaitu memformulasikan keinginan/tindakan penghadap/para penghadap ke dalam bentuk akta otentik dengan memperhatikan aturan hukum yang berlaku. Hal ini sebagaimana tertuang dalam Yurispridensi Mahkamah Agung (Putusan Mahkamah Agung Nomor 702 K/Sip/1973) yang menyebutkan :

“...Notaris fungsinya hanya mencatatkan/menuliskan apa-apa yang dikehendaki dan dikemukakan oleh para pihak yang menghadap Notaris tersebut. Tidak ada kewajiban bagi Notaris untuk menyelidiki secara materil apa-apa (hal-hal) yang dikemukakan oleh penghadap di hadapan Notaris tersebut".

Berdasarkan substansi atau makna Putusan Mahkamah Agung tersebut, jika akta yang dibuat oleh atau dihadapan Notaris bermasalah oleh para pihak sendiri, maka hal tersebut menjadi urusan para pihak itu sendiri, Notaris tidak perlu dilibatkan dan Notaris bukan pihak dalam akta. Namun dalam praktik sering pula Notaris dijadikan atau didudukkan sebagai tergugat atau turut tergugat oleh para pihak yang lainnya, yang merasa bahwa tindakan hukum yang tersebut dalam akta dikategorikan sebagai tindakan atau perbuatan hukum Notaris atau Notaris bersama-sama pihak lainnya yang juga tersebut dalam akta. Dalam posisi kasus seperti ini, yaitu kata dipermasalahkan oleh para pihak sendiri, dan akta tidak bermasalah dari aspek lahir, formal dan materiil, maka sangat bertentangan dengan kaidah hukum tersebut diatas.

Dalam praktik di Indonesia, sekurang-kurangnya terdapat 2 (dua) kemungkinan yang berkaitan dengan pemanggilan Notaris, pertama, Notaris yang bersangkutan diajukan dan dipanggil sebagai saksi di Pengadilan menyangkut akta yang dibuat dihadapan atau oleh Notaris yang dijadikan alat bukti. Kedua, Notaris yang diajukan sebagai tergugat atau turut tergugat di Pengadilan menyangkut akta yang dibuatnya dan dianggap merugikan bagi pihak penggugat, di Peradilan Umum (perkara perdata). Dalam hal menjadikan Notaris sebagai tergugat, gugatan ini langsung ditujukan kepada Notasi sendiri (tergugat tunggal), tetapi dalam hal ini ada batasan atau parameter untuk menggugat Notaris, yaitu jika para pihak yang menghadap Notaris (para pihak/penghadap yang namanya tercantum dalam akta) jika ingin melakukan pengingkaran.

Syarat pengingkaran yang ingin dilakukan terhadap Notaris sekurang-kurangnya memuat : (i) hari, tanggal, bulan, dan tahun menghadap; (ii) waktu (pukul) menghadap; (iii) tanda tangan yang tercantum dalam minuta akta; (iv) merasa tidak pernah menghadap; (v) akta tidak ditanda tangani di hadapan Notaris; (vi) akta tidak dibacakan; dan (vii) alasan lain berdasarkan formalitas akta (Habib Adjie, 2009:55). Pengingkaran atas hal-hal tersebut dilakukan dengan cara menggugat 
Notaris ke Pengadilan Negeri, dan para pihak wajib membuktikan hal-hal yang ingin diingkarinya, dan Notaris wajib mempertahankan aspek-aspek tersebut, sehingga dalam kaitan ini perlu dipahami dan diketahui kaidah hukum Notaris yaitu akta Notaris sebagai akta otentik mempunyai kekuatan pembuktian yang sempurna, sehingga tidak ada pihak yang menilai dan menyatakan tersebut wajib membuktikan penilaian atau pernyataannya sesuai aturan hukum.

Terkait dengan pengambilan minuta akta dan pemanggilan Notaris, untuk kepentingan proses peradilan, penyidik, penuntut umum, atau hakim, sebelumnya dalam UUJN 30/04 kewenangan tersebut diberikan kepada Majelis Pengawas Daerah. Setelah perubahan, dalam UUJN 2/14 kewenangan tersebut ada pada Majelis Kehormatan Notaris, sebagaimana termaktub dalam Pasal 66 UUJN. Pasal 66 UUJN menentukan sebagai berikut; (1) Untuk kepentingan proses peradilan, penyidik, penuntut umum, atau hakim dengan persetujuan majelis kehormatan Notaris berwenang; (a) mengambil fotokopi Minuta Akta dan/atau surat-surat yang dilekatkan pada Minuta Akta atau Protokol Notaris dalam penyimpanan Notaris; dan (b) memanggil Notaris untuk hadir dalam pemeriksaan yang berkaitan dengan Akta atau Protokol Notaris yang berada dalam penyimpanan Notaris; (2) Pengambilan fotokopi Minuta Akta atau surat-surat sebagaimana dimaksud pada ayat (1) huruf a, dibuat berita acara penyerahan; (3) Majelis kehormatan Notaris dalam waktu paling lama 30 (tiga puluh) hari kerja terhitung sejak diterimanya surat permintaan persetujuan sebagaimana dimaksud pada ayat (1) wajib memberikan jawaban menerima atau menolak permintaan persetujuan; (4) Dalam hal majelis kehormatan Notaris tidak memberikan jawaban dalam jangka waktu sebagaimana dimaksud pada ayat (3), majelis kehormatan Notaris dianggap menerima permintaan persetujuan.

Ketentuan mengenai Majelis Kehormatan Notaris dan kewenangannya selanjutnya diatur dalam Permenkum HAM 7/16 tentang Majelis Kehormatan Notaris, dimana Pasal 1 angka (1) menyebutkan, Majelis Kehormatan Notaris adalah suatu badan yang mempunyai kewenangan untuk melaksanakan pembinaan Notaris dan kewajiban memberikan persetujuan atau penolakan untuk kepentingan penyidikan dan proses peradilan, atas pengambilan fotokopi Minuta Akta dan pemanggilan Notaris untuk hadir dalam pemeriksaan yang berkaitan dengan Akta atau Protokol Notaris yang berada dalam penyimpanan Notaris.

Majelis Kehormatan Notaris terdiri atas Majelis Kehormatan Notaris Pusat dan Majelis Kehormatan Notaris Wilayah. Majelis Kehormatan Notaris Pusat dibentuk oleh Menteri dan berkedudukan di ibukota Negara Republik Indonesia. Sedangkan Majelis Kehormatan Notaris 
Wilayah dibentuk oleh Direktur Jenderal atas nama Menteri dan berkedudukan di ibukota Provinsi. Majelis Kehormatan Notaris Pusat mempunyai tugas melaksanakan pembinaan terhadap Majelis Kehormatan Wilayah yang berkaitan dengan tugasnya. Dalam melaksanakan tugasnya, Majelis Kehormatan Notaris Pusat mempunyai fungsi melakukan pengawasan terhadap Majelis Kehormatan Notaris Wilayah. Berdasarkan Pasal 18 Permenkum HAM 7/16, disebutkan bahwa tugas Majelis Kehormatan Notaris Wilayah yaitu; (a) melakukan pemeriksaan terhadap permohonan yang diajukan oleh penyidik, penuntut umum, dan hakim; dan (b) memberikan persetujuan atau penolakan terhadap permintaan persetujuan pemanggilan Notaris untuk hadir dalam penyidikan, penuntutan, dan proses peradilan.

Dalam melakukan pemeriksaan terhadap permohonan yang diajukan oleh penyidik, penuntut umum, dan hakim, dan juga memberikan persetujuan atau penolakan terhadap permintaan persetujuan pemanggilan Notaris untuk hadir dalam penyidikan, penuntutan, dan proses peradilan, dilakukan untuk menjaga menjaga martabat dan kehormatan Notaris dalam menjalankan profesi jabatannya, serta memberikan perlindungan kepada Notaris terkait dengan kewajiban Notaris untuk merahasiakan isi Akta yang berkaitan pula dengan sumpah jabatan Notaris. Disamping itu, terdapat pula ancaman pidana berdasarkan Pasal 322 KUHP terkait pelanggaran terhadap rahasia jabatan, membuat Notaris juga perlu berhati-hati terhadap segala keterangan yang dikeluarkannya.

Ketentuan atau mekanisme mengenai pengambilan Minuta Akta diatur dalam Pasal 20 angka (b) Permenkum HAM 7/16, berkaitan dengan pengambilan Minuta Akta berdasarkan keputusan Majelis Kehormatan Notaris Wilayah, disebutkan bahwa:

Kewenangan Majelis Kehormatan Notaris Wilayah berdasarkan keputusan rapat Majelis Kehormatan Notaris Wilayah meliputi; (a) pemeriksaan terhadap Notaris yang dimintakan persetujuan kepada Majelis Kehormatan Notaris Wilayah oleh penyidik, penuntut umum, atau hakim; (b) pemberian persetujuan atau penolakan terhadap permintaan persetujuan pengambilan fotokopi minuta akta dan/atau surat-surat yang dilekatkan pada minuta akta atau protokol Notaris dalam penyimpanan Notaris; dan (c) pemberian persetujuan atau penolakan terhadap permintaan persetujuan pemanggilan Notaris untuk hadir dalam penyidikan, penuntutan, dan proses peradilan yang berkaitan dengan akta atau protokol Notaris yang berada dalam penyimpanan Notaris.

Ketentuan Pasal 20 angka (b) Permenkum HAM 7/16 diatas mengatur mengenai kewenangan Majelis Kehormatan Notaris Wilayah dalam memberikan persetujuan terhadap 
pengambilan fotokopi minuta akta dan/atau surat-surat yang dilekatkan pada minuta akta atau protokol Notaris dalam penyimpanan Notaris. Sedangkan Pasal 20 angka (c) Permenkum HAM $7 / 16$, mengatur tentang pemberian persetujuan atau penolakan terhadap permintaan persetujuan pemanggilan Notaris untuk hadir dalam penyidikan, penuntutan, dan proses peradilan yang berkaitan dengan akta atau protokol Notaris yang berada dalam penyimpanan Notaris.

Syarat-syarat pemanggilan Notaris berkaitan dengan pemberian persetujuan kepada penyidik, penuntut umum, atau hakim untuk kepentingan proses peradilan dalam pemanggilan Notaris, berdasarkan Pasal 27 angka (1) Permenkum HAM 7/16, dilakukan dalam hal : (a) adanya dugaan tindak pidana berkaitan dengan minuta akta dan/atau surat-surat Notaris dalam penyimpanan Notaris; (b) belum gugur hak menuntut berdasarkan ketentuan tentang daluwarsa dalam peraturan perundangundangan di bidang hukum pidana; (c) adanya penyangkalan keabsahan tanda tangan dari salah satu pihak atau lebih; (d) adanya dugaan pengurangan atau penambahan atas Minuta Akta; atau (e) adanya dugaan Notaris melakukan pemunduran tanggal (antidatum).

Dalam melakukan pemeriksaan terhadap Notaris, Ketua Majelis Kehormatan Notaris Wilayah membentuk majelis pemeriksa yang beranggotakan sebanyak 3 (tiga) orang yang terdiri dari setiap unsur anggota Majelis Kehormatan Notaris Wilayah. Majelis pemeriksa terdiri atas 1 (satu) orang ketua merangkap anggota, dan 2 (dua) orang anggota. Dalam melakukan pemeriksaan, majelis pemeriksa dibantu oleh 1 (satu) sekretaris. Pembentukan majelis pemeriksa dilakukan dalam waktu paling lambat 5 (lima) hari kerja terhitung sejak tanggal laporan diterima. Majelis pemeriksa berwenang memeriksa dan memberikan persetujuan atau penolakan terhadap permintaan penyidik, penuntut umum, atau hakim terkait pengambilan fotokopi minuta akta dan surat-surat yang dilekatkan pada minuta akta dan/atau protokol Notaris dalam penyimpanan Notaris dan pemanggilan Notaris. Setiap hasil pemeriksaan majelis pemeriksa, dilaporkan kepada Ketua Majelis Kehormatan Notaris Wilayah. Ketua Majelis Kehormatan Notaris Wilayah wajib mengirim laporan setiap bulan kepada Ketua Majelis Kehormatan Notaris Pusat (Pasal 21 Permenkum HAM 7/16).

Dalam melakukan pemeriksaan kepada Notaris, Majelis pemeriksa apabila memiliki hubungan perkawinan atau hubungan darah, sebagaimana tertuang dalam ketentuan Pasal 22 angka (1) Permenkum HAM 7/16, diwajibkan untuk menolak untuk memeriksa Notaris yang mempunyai hubungan perkawinan atau hubungan darah dalam garis keturunan lurus ke bawah 
dan/atau ke atas tanpa pembatasan derajat, serta dalam garis ke samping sampai dengan derajat ketiga. Selanjutnya, dijelaskan dalam Pasal 22 angka (2), Ketua Majelis Dalam hal majelis pemeriksa mempunyai hubungan perkawinan atau hubungan darah, maka Ketua Majelis Kehormatan Notaris Wilayah menunjuk penggantinya.

Permohonan persetujuan pengambilan minuta akta atau protokol Notaris dan pemanggilan Notaris oleh pihak penyidik, penuntut umum, atau hakim untuk hadir dalam pemeriksaan yang terkait dengan akta atau protokol Notaris yang berada dalam penyimpanan Notaris, diajukan kepada Ketua Majelis Kehormatan Notaris Wilayah sesuai dengan wilayah kerja Notaris yang bersangkutan. Permohonan disampaikan secara tertulis dalam bahasa Indonesia dan tembusannya disampaikan kepada Notaris yang bersangkutan, yang paling sedikit memuat keterangan mengenai,(i) nama Notaris; (ii) alamat kantor Notaris; (iii) nomor akta dan/atau surat yang dilekatkan pada minuta akta atau protokol Notaris dalam penyimpanan Notaris; dan (iv) pokok perkara yang disangkakan.

Ketua Majelis Kehormatan Notaris Wilayah wajib memberikan jawaban berupa persetujuan atau penolakan terhadap permohonan sebagaimana disebutkan diatas, dalam jangka waktu paling lama 30 (tiga puluh) hari kerja terhitung sejak tanggal diterimanya permohonan, dianggap Majelis Kehormatan Notaris Wilayah menerima permintaan persetujuan. Akan tetapi, berdasarkan Pasal 66 angka (4), apabila Majelis Kehormatan Notaris tidak memberikan jawaban dalam jangka waktu 30 (tiga puluh) hari, Majelis Kehormatan Notaris dianggap menerima permintaan persetujuan.

Pemberian persetujuan atau penolakan dari Majelis Kehormatan Notaris setelah mendengar keterangan langsung dari Notaris yang bersangkutan, dituangkan ke dalam berita acara pemeriksaan. Apabila majelis pemeriksa memberikan persetujuan atas permohonan penyidik, penuntut umum, atau hakim, maka berdasarkan Pasal 25 angka (3) Permenkum HAM 7/16, Notaris wajib; (a) memberikan fotokopi minuta akta dan/atau surat-surat yang diperlukan kepada penyidik, penuntut umum, atau hakim; dan (b) menyerahkan fotokopi minuta akta dan/atau surat-surat dengan dibuatkan berita acara penyerahan yang ditandatangani oleh Notaris dan penyidik, penuntut umum, atau hakim dengan disaksikan oleh 2 (dua) orang saksi.

Selanjutnya, dalam Pasal 26 Permenkum HAM 7/16 yang mengatur tentang Pengambilan minuta akta dan/atau surat-surat Notaris dalam penyimpanan Notaris sebagaimana dimaksud dalam Pasal 25, dilakukan dalam hal; (a) adanya dugaan tindak pidana yang berkaitan dengan minuta akta dan/atau surat-surat yang dilekatkan pada minuta akta atau protokol Notaris dalam 
penyimpanan Notaris; (b) belum gugur hak menuntut berdasarkan ketentuan tentang daluwarsa dalam peraturan perundangundangan di bidang hukum pidana; (c) adanya penyangkalan keabsahan tanda tangan dari salah satu pihak atau lebih; (d) adanya dugaan pengurangan atau penambahan atas minuta akta; atau (e) adanya dugaan Notaris melakukan pemunduran tanggal (antidatum).

Berdasarkan uraian diatas, yang juga telah disinggung sebelumnya dalam latar belakang masalah terkait dengan status Notaris dalam memberikan keterangan, sebagaimana disinggung pula mengenai Permenkum HAM Nomor M.03.HT.03.10 Tahun 2007 tentang Pengambilan Minuta AKta dan Pemanggilan Notaris, maka dapat dikatakan bahwa baik UUJN, Permenkum HAM Nomor M.03.HT.03.10 Tahun 2007, maupun Permenkum HAM Nomor 7 tahun 2016, yang mengatur mengenai prosedur pemanggilan Notaris dan pengambilan Minuta Akta dalam kedudukan Notaris sebagai tergugat atau turut tergugat dalam perkara perdata tidak disebutkan secara tegas.

\section{Tanggung Jawab Notaris Dalam Pemeriksaan Perkara Perdata di Pengadilan Terkait Rahasia Jabatan dan Hak Ingkar Notaris}

Dalam suatu proses perkara perdata, salah satu tugas hakim adalah untuk menyelidiki apakah suatu hubungan hukum yang menjadi dasar gugatan benar-benar ada atau tidak. Seorang penggugat harus membuktikan dalil-dalil yang menjadi dasar gugatannya di Pengadilan agar gugatan tersebut dikabulkan oleh hakim. Sebab, pembuktian mengenai suatu peristiwa, mengenai adanya suatu hubungan hukum merupakan cara untuk meyakinkan hakim akan kebenaran dalildalil yang menjadi dasar gugatan, atau dalil-dalil yang dikemukakan oleh para pihak. Di dalam menjatuhkan beban pembuktian, hakim harus bertindak arif dan bijak sana, serta harus bersikap adil dan tidak memihak (Sudikno Mertokusumo, 2006:15)

Berkaitan dengan pengambilan Minuta Akta dalam pemeriksaan perkara perdata, diperlukan persetujuan dari Majelis Kehormatan Notaris oleh karena Minuta Akta merupakan arsip atau dokumen negara. Demikian juga segala dokumen yang disimpan dalam protokol Notaris merupakan arsip negara yang harus di simpan dan dipelihara oleh Notaris, sebagaimana tertuang dalam Pasal 4 angka (2) mengenai sumpah jabatan Notaris yang diantaranya : “...bahwa saya akan merahasiakan isi akta dan keterangan yang diperoleh dalam pelaksanaan jabatan saya...". Sebagai pejabat umum yang menjalankan sebagian tugas negara dalam bidang hukum perdata, 
maka pengambilan Minuta Akta haruslah memerlukan persetujuan dari negara, dalam hal ini melalui persetujuan Majelis Kehormatan Notaris.

Persetujuan oleh Majelis Kehormatan Notaris dimaksudkan untuk memberikan perlindungan hukum, tidak hanya terhadap Notaris, tetapi juga kepada pihak yang membuat akta tersebut dan merupakan upaya menjaga kerahasiaan akta otentik karena merupakan dokumen atau arsip negara. Dibutuhkannya persetujuan Majelis Kehormatan Notaris dalam pengambilan Minuta Akta/fotokopi Minuta Akta, merupakan upaya menjaga kerahasiaan akta otentik menjadi penting, karena Notaris dalam menjalankan jabatannya terikat pada kewajiban untuk merahasiakan segala sesuatu mengenai akta yang dibuatnya.

Sebagaimana telah di singgung diatas, Notaris dalam menjalankan tugas jabatannya, tidak jarang ditemui permasalahan-permasalahan, baik terhadap akta yang dibuatnya maupun terhadap para pihak yang terlibat dalam pembuatan akta tersebut. Notaris seringkali diikut-sertakan dalam sengketa, baik sebagai tergugat ataupun turut tergugat, yang terjadi antara pihak oleh karena akta yang dibuatnya menimbulkan kerugian bagi salah satu pihak. Hal ini mengudang perdebatan tentang apakah Notaris dapat didudukan sebagai tergugat atau turut tergugat, atau sebagai saksi, bilamana akta yang dibuatnya disengketakan, mengingat kedudukan Notaris sendiri yang kewenangannya hanya membuat akta.

Perlu ditegaskan bahwa kewenangan Notaris dalam pembuatan akta, tidak berarti Notaris dapat secara bebas berdasarkan kehendaknya membuat akta otentik tanpa keberadaan para pihak yang dilibatkan dalam pembuatan akta. Akta notaris pada dasarnya adalah akta para pihak-pihak yang berkepentingan, bukan aktanya notaris yang bersangkutan. Karena itulah manakala terjadi sengketa dalam perjanjian yang termuat dalam akta notaris yang dibuat bagi para pihak dan dihadapan notaris, maka yang terikat hanyalah mereka yang mengadakan perjanjian itu sendiri. Notaris tidak terikat untuk memenuhi janji ataupun kewajiban apapun seperti yang tertuang dalam akta notaris yang dibuat di hadapan para pihak, dan notaris sama sekali berada di luar mereka yang menjadi pihak-pihak (Winda Ayu Swastika, 2016:197).

Sementara itu, dalam praktik, perkataan turut tergugat dipergunakan bagi orang-orang yang tidak menguasai barang sengketa atau tidak berkewajiban untuk melakukan sesuatu, hanya demi lengkapnya suatu gugatan harus diikutsertakan. Mereka dalam petitum hanya sekedar dimohonkan agar tunduk dan taat terhadap putusan Hakim (Retnowulan Sutantio dan Iskandar Oeripkarta, 
1979:2). Hal ini juga senada dengan Yurisprudensi Mahkamah Agung dalam Putusan Mahkamah Agung Nomor 1642 k/pdt/2005, yaitu :

"dimasukkan sebagai pihak yang digugat atau minimal didudukkan sebagai turut tergugat. Hal ini terjadi dikarenakan adanya keharusan para pihak dalam gugatan harus lengkap sehingga tanpa menggugat yang lain-lain itu maka subjek gugatan menjadi tidak lengkap."

Selain itu, dalam salah satu pertimbangan tersebut juga disebutkan sebagai berikut :

"Ketidaklengkapan dalam merumuskan subjek yang seharusnya menjadi Tergugatnya, maka gugatan yang diajukan dapat dianggap telah terjadi error in persona/kesalahan subjek hukum maka gugatan tidak bisa diterima/Niet Ontvenkel Ijkverklaard."

Berdasarkan Yurisprudensi Mahkamah Agung tersebut, dapat diketahui bahwa ketika seorang Notaris dilibatkan sebagai salah satu pihak dalam gugatan, hal itu hanyalah untuk melengkapi subyek/para pihak dalam gugatan, karena suatu gugatan yang tidak lengkap rumusan subjeknya akan menjadikan gugatan error in persona, sehingga gugatan tersebut tidak dapat diterima.

Dalam hal kedudukan Notaris sebagai saksi dalam perkara perdata, bukanlah meruakan suatu kewajiban yang bersifat imperatif kecuali ada alasan yang sah untuk menghadirkan saksi yang ditentukan dalam Pasal 139 ayat (1) dan Pasal 143 HIR, yaitu keterangan yang akan diberikan sangat urgen dan relevan dalam meneguhkan dalil penggugat atau bantahan penggugat. Bagi kesaksian Notaris yang berkaitan dengan kata otentik, yang dibuat oleh atau dihadapannya dalam perkara perdata, bukan merupakan kewajiban yang imperatif, sebab akta otentik telah memberikan kekuatan bukti yang cukup tanpa perlu alat bukti lain (Pieter Latumenten, Majalah Renvoi Nomor 12.60.V, 2008).

Sumpah Jabatan Notaris dalam Pasal 4 dan kewajiban Notaris dalam Pasal 16 huruf (f) UUJN, mewajibkan Notaris untuk tidak berbicara sepanjang tidak ditentukan lain oleh UndangUndang, sekalipun di Pengadilan. Artinya, tidak diperbolehkan untuk memberi kesaksian mengenai apa yang dimuat di dalam aktanya. Kewajiban ini mengesampingkan kewajiban umum untuk memberikan kesaksian sebagaimana yang dimaksud dalam Pasal 1909 BW. Menurut Pasal 1909 BW, setiap orang yang cakap untuk menjadi saksi, diharuskan memberikan kesaksian di muka Hakim, namun dapat minta dibebaskan dari kewajibannya memberi kesaksian bagi mereka yang karena kedudukannya, pekerjaannya, atau jabatannya menurut Undang-Undang diwajibkan merahasiakan sesuatu, namun hal-hal tersebut mengenai hal-hal yang dipercayakan kepadanya. 
Disamping itu, ancaman pidana berdasarkan Pasal 322 KUHP terkait pelanggaran terhadap rahasia jabatan juga membuat Notaris harus berhati-hati terhadap setiap keterangan yang dikeluarkannya. Artinya, kepentingan untuk menjaga kerahasiaan kata berdasarkan sumpah Notaris, dan kewajiban untuk memberikan kesaksian di Pengadilan, perlu dilakukan berdasarkan pertimbangan-pertimbangan yang matang, agar setiap pihak, baik para pihak dalam akta, atau Notaris itu sendiri, mendapat perlindungan hukum yang sama.

Dalam teorinya, pemberian kesaksian Notaris di Persidangan, terdapat 2 (dua) aliran yaitu, pertama, aliran Rahasia Absolut, yang berpendirian bahwa semua hal yang bersangkutan dengan isi akta yang dibuatnya dan rahasia klien mutlak harus dirahasiakan tanpa pengecualian. Ajaran rahasia absolut ini telah menjurus mengagungkan fungsi rahasia jabatan yang dimiliki seseorang secara totalitas. Kedua, aliran Rahasia Nisbi, yang berpendirian bahwa kewajiban menyimpan rahasia dapat dilepaskan apabila ada kepentingan yang lebih tinggi yaitu kepentingan umum atau negara (Yahya Harahap, 2008:670).

Dalam pada itu, pada dasarnya pemberian kesaksian oleh Notaris bersifat fakultatif, artinya berdasarkan atau tergantung penilaian Notaris itu sendiri, meskipun pada akhirnya tergantung dari pemberian persetujuan yang diberikan oleh Majelis Kehormatan Notaris. Akan tetapi, bagi Notaris itu sendiri, bahwa putusan untuk menggunakan atau tidak menggunakan hak ingkar, patutlah dipertimbangkan berkaitan dengan pengetahuan dan hati nuraninya. Dalam hal demikian, Notaris yang bersangkutan wajib tetap hadir memenuhi panggilan, sekaligus juga dapat menggunakan hak ingkarnya dengan mengajukan permohonan kepada hakim sebelum dilakukan sumpah sebelum diambil keterangannya. Dasar pertimbangannya yaitu, bahwa hak ingkar tersebut diberikan kepada Notaris oleh Undang-Undang, yaitu melindungi Notaris dari kewajiban menjaga rahasia jabatan dan kepercayaan masyarakat terhadapnya.

Berdasarkan Pasal 146 HIR/ Pasal 174 Rgb ayat (2) yang mengatur bahwa beralasan atau tidaknya kewajiban untuk memegang rahasia yang dikemukakan itu, diserahkan kepada penilaian hakim. Jika kemudian hakim mengabulkan penggunaan hak ingkar oleh Notaris, maka Notaris yang bersangkutan dibebaskan dari kewajiban memberi keterangan. Sehingga dengan demikian, rahasia Jabatan Notaris menjadi terlindungi dan sekaligus terbebas dari sanksi hukum karena telah melaksanakan kewajiban rahasia jabatan dan penggunaan hak ingkar. Namun apabila hakim menolak penggunaan hak ingkar Notaris, maka kewajiban Notaris untuk merahasiakan isi akta juga berakhir. 
Dalam suatu artikel di rubrik hukumonline.com pada hari selasa tanggal 26 November 2013 berjudul "Hak Ingkar Bukan Untuk Lindungi Notaris", Ketua DKP INI, Badar Baraba, mengingatkan bahwa Notaris tidak dapat bersembunyi dibalik hak ingkar ketika Notaris terlibat dalam kasus pidana. Badar melanjutkan bahwa, meski demikian, sebenarnya sesuai UndangUndang, Notaris tak bisa diperiksa menjadi saksi terkait akta penggunaan akta. Selain karena adanya hak ingkar, Pasal 322 ayat (1) KUHP dan Pasal 170 ayat (1) KUHAP terkait kewajiban menyimpan rahasia jabatan, sehingga dapat dibebaskan menjadi saksi. Notaris hanya bisa menjadi saksi terhadap tindak pidana yang disangkakan pada seseorang yang dilakukan atau terjadi di hadapan notaris.

Mengenai masalah ini, dengan berdasarkan petunjuk MA Nomor : MA/Pemb/3425/86 tanggal 12 April 1986, menurut Sofyan Sitompul menyebutkan bahwa bagaimana posisi dan bentuk perlindungan notaris dalam peradilan pidana belum ditemukan karena semuanya serba relatif dan kasuistis. Misalnya, notaris yang dipanggil sebagai saksi wajib hadir dan memberikan keterangan secara benar mengingat sumpah jabatan dan UU Jabatan Notaris. Notaris dapat meminta dibebaskan dari kewajiban untuk memberikan keterangan berdasarkan pasal 170 KUHAP yang mengatur hak untuk menolak memberikan keterangan kepada pihak karena notaris tersebut diwajibkan untuk menyimpan rahasia jabatan. Hak ingkar notaris dapat dilepaskan demi kepentingan umum yang berkaitan isi akta.

Berkaitan dengan penggunaan hak ingkar Notaris di pengadilan, apabila akhirnya hakim menolak permohonan hak ingkar yang diajukan Notaris dan memutuskan bahwa Notaris harus memberikan keterangan di Pengadilan, maka sudah semestinya hakim atau Pengadilan memberikan perlindungan hukum terhadap Notaris dengan membebaskan Notaris dari segala tuntutan hukum pihak-pihak yang berkepentingan. Kewajiban memberikan keterangan di Pengadilan mengakibatkan Notaris tidak dapat lagi menggunakan hak ingkarnya dan sudah dibebaskan dari kewajiban untuk tidak berbicara. Dengan demikian, Notaris juga dapat dibebaskan dari sanksi yang ditetapkan dalam Pasal 322 KUHP.

Akan tetapi, perlindungan hukum tersebut diberikan sepanjang Notaris yang bersangkutan hanya memberikan keterangan menyangkut kewenangannya dalam membuat akta dan tidak melibatkan diri dalam materi-materi perjanjian yang telah dibuat dan diterima antar para pihak yang bersengketa. Sebagaiman telah dijelaskan sebelumnya bahwa dalam hal pembuatan partij akta atau akta para pihak, Notaris hanya bertanggung jawab terhadap kebenaran formil dari akta 
tersebut, sementara kebenaran materil dari apa yang diperjanjikan oleh para pihak hanya diketahui oleh para pihak itu sendiri.

\section{SIMPULAN}

Berdasarkan ketentuan peraturan perundang-undangan yang mengatur tentang mekanisme pengambilan Minuta Akta dan Pemanggilan Notaris dengan persetujuan Majelis Kehormatan Notaris dalam pemeriksaan perkara perdata di Pengadilan, dapat disimpulkan bahwa untuk kepentingan proses peradilan, penyidik, penuntut umum, atau hakim, terlebih dahulu harus berdasarkan persetuuan Majelis Kehormatan Notaris. Di samping itu, berdasarkan peraturan perundang-undangan yang mengatur tentang pengambilan Minuta Akta dan Pemanggilan Notaris, kedudukan Notaris sebagai tergugat atau turut tergugat dalam perkara perdata tidak disebutkan secara tegas. Beberapa hal penting yang mengatur pengambilan Minuta Akta dan Pemanggilan Notaris sebagian besar hanya mengatur tentang keududkan Notaris sebagai saksi atau tersangka dalam perkara pidana.

Berkaitan dengan tanggung Jawab notaris dalam pemeriksaan perkara perdata di pengadilan terkait rahasia jabatan dan hak ingkar notaris, pada dasarnya pemberian keterangan di pengadilan oleh Notaris terkait akta yang dibuatnya bersifat fakultatif, walaupun pada akhirnya keputusan akhir dari pemberian izin tersebut berdasarkan persetujuan Majelis Kehormatan Notaris, ataupun juga berdasarkan keputusan hakim yang mewajibkan Notaris memberikan keterangan di pengadilan sehingga hak ingkar Notaris yang berkaitan dengan sumpah jabatan Notaris menjadi berakhir. Dalam kondisi yang demikian, Notaris harus mendapatkan perlindungan hukum atas keterangan yang diberikannya, termasuk bebas dari sanksi hukum yang mengatur tentang rahasia jabatan.

\section{DAFTAR PUSTAKA}

Adjie, Habib, 2009, Meneropong Khazanah Notaris dan PPAT Indonesia : Kumpulan Tulisan tentang Notaris dan PPAT, PT. Aditya Bakti, Bandung. , 2009, Hukum Notaris Indonesia : Tafsir tematik Terhadap UU. No. 30 Tahun 2004 tentang Jabatan Notaris, PT. Refika Aditama, Bandung. , 2011, Kebatalan dan Pembatalan Akta Notaris, PT. Refika Aditama, Bandung.

Bidara,O, dan Martin P. Bidara, 1987, Ketentuan Perundang-undangan, Yurisprudensiyurisprudensi dan Pendapat Mahkamah Agung RI tentang Hukum Acara Perdata, Pradya Paramita, Jakarta.

Harahap, Yahya, 2008, Hukum Acara Perdata, Sinar Grafika, Jakarta. Kitab Undang-Undang Hukum Perdata (KUHper) 
Kitab Undang-Undang Hukum Pidana (KUHP)

Marzuki, Peter Mahmud, 2005, Penelitian Hukum, Kencana, Jakarta.

Mertokusumo, Sudikno, 2006, Hukum Acara Perdata Indonesia, Liberty, Yogyakarta.

Notodisoerojo, R. Sugondo, 1993, Hukum Notariat di Indonesia : Suatu Penjelasan, Raja Grafindo Persada, Jakarta.

Prabawa, Bagus Gede Ardiartha, Analisis Yuridis Tentang Hak Ingkar Notaris Dalam Hal Pemeriksaan Menurut Undang-Undang Jabatan Notaris Dan Kode Etik Notaris, Jurnal Ilmiah Prodi Magister Kenotariatan, 2016 -2017.

Prajitno, A.A. Andi, 2010, Apa dan Siapa Notaris di Indonesia, Putra Media Nusantara, Surabaya. Sjaifurrachman, 2011, Aspek Pertanggungjawaban Notaris dalam Pembuatan Akta, Mandar maju, Bandung.

Suantio, Retnowulan, et.al, 1979, Hukum Acara Perdata Dalam Teori dan Praktek, mandar maju, Bandung.

Subekti, R, R. Tjitrosudibio, 2005, Kitab Undang-Undang Hukum Perdata (Burgerlijk Wetboek), Pradya Paramitha, Jakarta.

Sukisno, Djoko, 2008, Pengabilan Fotokopi Minuta Akta dan Pemanggilan Notaris, Mimbar Hukum, Volume 20.

Swastika, Winda Ayu, 2016, Politik Hukum Pembentukan Majelis Kehormatan Notaris, Lex Renaissance, Volume 1.

Syahrani, Rinduan, 1988, Hukum Acara Perdata dalam Lingkungan Peradilan Umum, Pustaka Kartini, Jakarta.

Tobing, G.H.S Lumban, 1983, Peraturan Jabatan Notaris, Erlangga, Jakarta.

Waluyo, Bambang, 1992, Implementasi Kekuasaan Kehakiman, Sinar Grafika, Jakarta.

Undang-Undang Republik Indonesia Nomor 2 Tahun 2014 tentang Perubahan Atas UndangUndang Nomor 30 Tahun 2004 tentang Jabatan Notaris

Peraturan Menteri Hukum Dan Hak Asasi Manusia Republik Indonesia Nomor 7 Tahun 2016 tentang Majelis Kehormatan Notaris

Peraturan Menteri Hukum Dan Hak Asasi Manusia Republik Indonesia Nomor: M.03.Ht.03.10 tahun 2007 tentang Pengambilan Minuta Akta Dan Pemanggilan Notaris 